ISSN 2442-3041

Math Didactic: Jurnal Pendidikan Matematika

Vol. 2, No. 3, September - Desember 2016

(c) STKIP PGRI Banjarmasin

\title{
PENGARUH GAYA BELAJAR TERHADAP HASIL BELAJAR MATEMATIKA SISWA KELAS VIII SMPN 2 BANJARMASIN TAHUN AJARAN 2015/2016
}

\author{
Indah Budiarti, Abdul Jabar \\ Program Studi Pendidikan Matematika STKIP PGRI Banjarmasin \\ timpils@yahoo.com, abdul.jabar.bjm@gmail.com
}

\begin{abstract}
Abstrak: Gaya belajar siswa merupakan salah satu unsur yang penting yang harus diperhatikan dalam proses belajar untuk mewujudkan tujuan pembelajaran matematika yang diharapkan. Bobbi DePorter dan Mike Hernacki dalam bukunya Quantum Learning mengatakan bahwa gaya belajar merupakan kunci untuk mengembangkan kinerja dalam pekerjaan, sekolah, dan dalam situasi antar pribadi, dengan begitu gaya belajar akan mempengaruhi seseorang dalam menyerap dan mengolah informasi sehingga akan mempengaruhi prestasi yang dicapai (DePotter, 1999:110). Adapun tujuan penelitian ini adalah untuk mengetahui adakah pengaruh signifikan gaya belajar terhadap hasil belajar matematika siswa kelas VIII SMPN 2 Banjarmasin tahun ajaran 2015/2016. Penelitian ini termasuk jenis penelitian korelasional dan expost facto dengan pendekatan kuantitatif.Populasi dalam penelitian ini adalah seluruh kelas VIII SMPN 2 Banjarmasin tahun ajaran 2015/2016. Teknik pengumpulan data yang digunakan dalam penelitian ini adalah kuesioner. Analisis data menggunakan SPSS. Hasil Penelitian yaitu Tidak Terdapat pengaruh signifikan gaya belajar terhadap hasil belajar matematika siswa kelas VIII SMPN 2 Banjarmasin tahun ajaran 2015/2016.
\end{abstract}

Kata kunci: gaya belajar, expost facto, hasil belajar

Gaya belajar siswa merupakan salah satu unsur yang penting yang harus diperhatikan dalam proses belajar untuk mewujudkan tujuan pembelajaran matematika yang diharapkan. Bobbi DePorter dan Mike Hernacki dalam bukunya Quantum Learning mengatakan bahwa gaya belajar merupakan kunci untuk mengembangkan kinerja dalam pekerjaan, sekolah, dan dalam situasi antar pribadi, dengan begitu gaya belajar akan mempengaruhi seseorang dalam menyerap dan mengolah informasi sehingga akan mempengaruhi prestasi yang dicapai (DePotter, 1999:110).

Menurut wawancara dengan salah satu guru matematika kelas VIII SMPN 2 Banjarmasin pada bulan maret 2015, sebagian besar siswa dalam menyelesaikan permasalahan matematika mengikuti cara seperti apa yang dicontohkan oleh guru. Ketika permasalahan yang dihadapinya agak berbeda penyajiannya mereka merasa kesulitan untuk menyelesaikannya sehingga kembali bertanya kepada guru bagaimana cara menyelesaikannya. diperlukan kemampuan bergaya belajar 
sehingga siswa dapat memilih dan menerapkan cara/metode yang tepat guna menyelesaikan permasalahan yang dihadapinya dengan benar.

Dari penjelasan di atas, peneliti ingin mengetahui apakah ada pengaruh antara gaya belajar terhadap hasil belajar matematika siswa kelas VIII SMPN 2 Banjarmasin tahun ajaran 2015/2016.

Adapun rumusan masalah pada penelitian ini yaitu adakah pengaruh signifikan gaya belajar terhadap hasil belajar matematika siswa kelas VIII SMPN 2 Banjarmasin tahun ajaran 2015/2016?

Tujuan penelitian ini untuk mengetahui adakah pengaruh signifikan gaya belajar terhadap hasil belajar matematika siswa kelas VIII SMPN 2 Banjarmasin tahun ajaran 2015/2016?

Manfaat yang diharapkan dari penelitian ini adalah secara teoritis dapat memberikan sumbangan kepada pembelajaran matematika utamanya dalam mengetahui adakah pengaruh signifikan gaya belajar terhadap hasil belajar matematika.

\section{Gaya Belajar}

Menurut Bobbi DePorter dan Mike Hernacki gaya belajar merupakan suatu kombinasi dari bagaimana seseorang menyerap, dan kemudian mengatur serta mengolah informasi (DePotter, 1999:111). Menurut Nasution gaya belajar atau "learning style" siswa yaitu cara siswa bereaksi dan menggunakan perangsangperangsang yang diterimanya dalam proses belajar (Nasution, 2008:93). Para peneliti menemukan adanya berbagai gaya belajar pada siswa yang dapat digolongkan menurut kategori-kategori tertentu. Mereka berkesimpulan, bahwa

1) Tiap murid belajar menurut cara sendiri yang kita sebut gaya belajar. Juga guru mempunyai gaya mengajar masing-masing.

2) Kita dapat menemukan gaya belajar itu dengan instrumen tertentu.
3) Kesesuaian gaya mengajar dengan gaya belajar mempertinggi efektivitas belajar.

Dari pengertian-pengertian di atas, disimpulkan bahwa gaya belajar adalah cara yang cenderung dipilih siswa untuk bereaksi dan menggunakan perangsangperangsang dalam menyerap dan kemudian mengatur serta mengolah informasi pada proses belajar.

\section{Gaya Belajar VAK (Visual, Auditorial, Kinestetik)}

Banyak ahli yang menggunakan istilah berbeda-beda dalam memahami gaya belajar ini. Tetapi secara umum, menurut Bobby DePotter terdapat dua benang merah yang disepakati tentang gaya belajar ini. Pertama adalah cara seseorang menyerap informasi dengan mudah, yang disebut sebagai modalitas, dan kedua adalah cara orang mengolah dan mengatur informasi tersebut. Modalitas belajar adalah cara kita menyerap informasi melalui indera yang kita miliki. Masing-masing orang mempunyai kecenderungan berbeda-beda dalam menyerap informasi. Terdapat tiga modalitas belajar ini, yaitu apa yang sering disingkat dengan VAK: Visual, Auditory, Kinestethic.

Dari beberapa uraian diatas dapat pula dijelaskan secara lebih ringan tentang gaya belajar seseorang, dimana orang bergaya belajar visual akan sangat mudah melihat atau membayangkan apa yang dibicarakan. Mereka sering melihat gambar yang berhubungan dengan kata atau perasaan dan mereka akan mengerti suatu informasi bila mereka melihat kejadian, melihat informasi itu tertulis atau dalam bentuk gambar.

Orang bergaya belajar auditori mengekspresikan diri mereka melalui suara, baik itu melalui komunikasi internal dengan diri sendiri ataupun eksternal dengan orang lain. Bila hendak menuliskan sesuatu, orang ini akan mendengar suara dari apa yang akan dia tulis. Bila ia harus bertemu dan akan berbicara dengan 
seseorang yang baru ia kenal, ia akan melakukan latihan mental mengenai apa saja yang akan ia katakan dan bagaimana cara mengatakannya.

Orang bergaya belajar kinestetik sangat peka terhadap perasaan atau emosi dan pada sensasi sentuhan dan gerakan. Bila diminta untuk menuliskan suatu kata, orang ini akan merasakan dulu kata tersebut baru setelah itu menuliskannya. Orang bergaya belajar kinestetik akan belajar maksimal dalam suatu kondisi dimana banyak keterlibatan fisik dan gerakan (Gunawan, 2003: 149).

Dalam penelitian ini gaya belajar yang dimaksudkan adalah kecendrungan masing masing individu untuk menggunakan perangsang atau alat indra tertentu untuk menyerap informasi dalam belajar, dimana disini dikhususkan pada indra penglihatan (visual), indra pendengaran (auditorial), dan tindakan atau gerak dalam gaya belajar disebut juga sebagai kinestetik.

\section{Hasil Belajar}

Belajar merupakan suatu proses perubahan tingkah laku. Sebuah proses maka sudah barang tentu harus ada yang diproses dan akhir dari proses. Akhir dari proses inilah yang disebut dengan hasil belajar. Hasil belajar ini terdiri dari perubahan tingkah laku tersebut.

Hal ini sejalan dengan pendapat Nasution tentang hasil belajar yaitu:

"Suatu perubahan yang terjadi pada individu yang belajar bukan saja perubahan mengenai pengetahuan tetapi juga dalam bentuk kecakapan, kebiasaan, sikap, pengertian, penguasaan dan penghargaan dalam diri pribadi individu yang belajar" (Nasution, 1982:25).

Sedangkan

Arikunto mendefenisikan bahwa hasil belajar itu merupakan hasil akhir setelah mengalami proses belajar, dimana tingkah laku itu tampak dalam bentuk perbuatan yang dapat diamati atau diukur (Arikunto, 1992:133).
Jadi Hasil belajar siswa adalah hasil yang diperoleh siswa setelah melakukan suatu proses belajar matematika selama kurun waktu tertentu dimana hasil belajar tersebut bisa diukur melalui suatu tes.

Hasil belajar juga dapat dikatakan sebagai kemampuan yang dimiliki siswa setelah ia menerima pengalaman belajarnya. Hasil belajar mempunyai peranan penting dalam proses pembelajaran. Proses penilaian terhadap hasil belajar dapat memberikan informasi kepada guru tentang kemajuan siswa dalam upaya mencapai tujuan-tujuan belajarnya melalui kegiatan belajar. Selanjutnya dari informasi tersebut guru dapat menyusun dan membina kegiatan-kegiatan siswa lebih lanjut, baik untuk keseluruhan kelas maupun individu.

Hasil belajar dibagi menjadi tiga macam hasil belajar yaitu: (a). Keterampilan dan kebiasaan; (b). Pengetahuan dan pengertian; (c). Sikap dan cita-cita, yang masing-masing golongan dapat diisi dengan bahan yang ada pada kurikulum sekolah (Sudjana, 2004:22).

Secara umum faktor-faktor yang mempengaruhi hasil belajar yaitu:

\section{a. Faktor Internal (dari dalam individu yang belajar).}

Faktor yang mempengaruhi kegiatan belajar ini lebih ditekankan pada faktor dari dalam individu yang belajar. Adapun faktor yang mempengaruhi kegiatan tersebut adalah faktor psikologis, antara lain yaitu: motivasi, perhatian, pengamatan, tanggapan dan lain sebagainya.

\section{b. Faktor Eksternal (dari luar individu yang belajar).}

Pencapaian tujuan belajar perlu diciptakan adanya sistem lingkungan belajar yang kondusif. Hal ini akan berkaitan dengan faktor dari luar siswa. Adapun faktor yang mempengaruhi adalah mendapatkan pengetahuan, penanaman konsep dan keterampilan, dan pembentukan sikap. 
Hasil belajar yang diperoleh siswa adalah sebagai akibat dari proses belajar yang dilakukan oleh siswa, harus semakin tinggi hasil belajar yang diperoleh siswa. Proses belajar merupakan penunjang hasil belajar yang dicapai siswa (Sudjana, 1989:111).

\section{Hipotesis Penelitian}

Berdasarkan atas rumusan masalah dan kajian teori yang telah dikemukakan, maka diajukan hipotesis yaitu :

Terdapat pengaruh signifikan gaya belajar terhadap hasil belajar matematika SISWA kelas VIII SMPN 2 Banjarmasin tahun ajaran 2015/2016.

\section{Metode Penelitian}

\section{Jenis Penelitian}

Penelitian ini termasuk jenis penelitian korelasional dan expost facto dengan pendekatan kuantitatif. Penelitian korelasional merupakan penelitian yang dimaksudkan untuk mengetahui ada tidaknya hubungan antara dua atau beberapa variabel (Arikunto, 2000:326). Di katakan expost facto karena di dalam penelitian ini tidak dibuat perlakuan pada objek penelitian melainkan hanya mengungkapkan fakta pada diri responden. Pendekatan yang digunakan dalam penelitian ini adalah pendekatan kuantitatif, artinya semua informasi atau data penelitian diwujudkan dalam bentuk angka yang dianalisis dengan statistik dan hasilnya dideskripsikan.

\section{Populasi dan Sampel Penelitian a. Populasi}

Populasi dalam penelitian ini adalah seluruh kelas VIII SMPN 2 Banjarmasin tahun ajaran 2014/2015 yang terdiri dari 6 kelas.

\section{b. Sampel Penelitian}

Sampel adalah bagian dari populasi untuk dijadikan sebagai contoh dengan harapan contoh yang diambil dari populasi tersebut dapat mewakili atau representatif terhadap populasinya. Mengingat jumlah populasi yang sangat besar dan terbatasnya kemampuan peneliti maka penelitian ini hanya dilakukan terhadap sampel yang mewakili populasi.

\section{Sumber Data}

Sumber data dalam penelitian ini adalah:

a. Data primer bersumber dari kelas VIII SMPN 2 Banjarmasin yang menjadi sampel pada penelitian ini.

b. Data sekunder bersumber dari Kantor Tata Usaha dan Guru bidang studi matematika SMPN 2 Banjarmasin.

\section{Teknik Pengumpulan Data}

Teknik pengumpulan data yang digunakan dalam penelitian ini adalah:

\section{a. Metode Kuesioner}

Metode ini merupakan cara pengumpulan data dalam bentuk sejumlah pertanyaan atau pernyataan tertulis yang digunakan untuk memperoleh informasi dari responden dalam arti laporan kepribadiannya atau dalam hal-hal yang diketahuinya (Arikunto, 2000:134).

\section{b. Metode Tes}

Tes digunakan untuk mengetahui hasil belajar siswa selama kurun waktu tertentu.

\section{Instrumen Penelitian}

Instrumen penelitian atau instrumen pengumpulan data adalah alat bantu yang dipilih dan digunakan oleh peneliti dalam kegiatannya mengumpulkan data agar kegiatan tersebut menjadi sistematis dan dipermudah olehnya (Arikunto, 200:158). Instrumen yang digunakan dalam penelitian ini berupa 
angket. Angket yang digunakan adalah jenis angket tertutup yaitu, suatu angket yang pertanyaan/pernyataan dan alternatif jawabannya telah ditentukan sehingga responden tinggal memilih jawaban yang diinginkan.

\section{a. Angket Gaya belajar}

Aspek-aspek yang diukur meliputi gaya belajar visual, auditorial dan kinestetik. Angket gaya belajar terdiri atas beberapa pernyataan. Butir angket dinyatakan dalam dua bentuk, yaitu pernyataan yang bersifat positif dan pernyataan yang bersifat negatif.

\section{b. Tes hasil belajar}

Dalam hal ini dilakukan tes hasil belajar pada kelas VIII SMPN 2 Banjarmasin semester ganjil.

\section{Teknik Analisis Data}

Data yang diperoleh dianalisis dengan bantuan software SPSS

\section{Hasil dan Pembahasan}

\begin{tabular}{|c|c|c|c|}
\hline & & $\begin{array}{c}\text { hasil } \\
\text { belajar }\end{array}$ & $\begin{array}{c}\text { gaya } \\
\text { belajar }\end{array}$ \\
\hline \multirow[t]{3}{*}{ hasil belajar } & $\begin{array}{l}\text { Pearson } \\
\text { Correlation }\end{array}$ & 1 &,- 106 \\
\hline & Sig. (2-tailed) & & , 143 \\
\hline & $\mathrm{N}$ & 192 & 192 \\
\hline \multirow[t]{3}{*}{ gaya belajar } & $\begin{array}{l}\text { Pearson } \\
\text { Correlation }\end{array}$ &,- 106 & 1 \\
\hline & Sig. (2-tailed) &, 143 & \\
\hline & $\mathrm{N}$ & 192 & 192 \\
\hline
\end{tabular}

Menentukan Hipotesis

Ho: Tidak ada hubungan secara signifikan antara gaya belajar dengan hasil belajar Ha: Ada hubungan secara signifikan antara gaya belajar dengan hasil belajar

Ketentuan Jika sig $<0,05$ maka Ho ditolak Jika sig $>0,05$ maka Ho di terima

Diliat dari tabel korelasi dapat diketahui bahwa sig 0,143>0,05 maka Ho diterima berarti Tidak terjadi hubungan signifikan antara gaya belajar terhadap hasil belajar.

Variables Entered/Removed ${ }^{\mathrm{b}}$

\begin{tabular}{|c|c|c|c|c|}
\hline Model & \multicolumn{2}{|c|}{$\begin{array}{l}\text { Variables } \\
\text { Entered }\end{array}$} & $\begin{array}{l}\text { Variables } \\
\text { Removed }\end{array}$ & Method \\
\hline 1 & \multicolumn{2}{|c|}{ gaya belajar ${ }^{a}$} & . & Enter \\
\hline \multicolumn{5}{|c|}{ a. All requested variables entered. } \\
\hline \multicolumn{5}{|c|}{$\begin{array}{l}\text { b. Dependent Variable: hasil belajar } \\
\text { Model Summary }\end{array}$} \\
\hline Model & $\mathrm{R}$ & R Square & $\begin{array}{l}\text { Adjusted R } \\
\text { Square }\end{array}$ & $\begin{array}{l}\text { Std. Error of } \\
\text { the Estimate }\end{array}$ \\
\hline 1 & $106^{\mathrm{a}}$ & ,011 &, 006 & 4,420 \\
\hline
\end{tabular}

Dilihat dari $\mathrm{R}$ atau nilai koefisien korelasi yaitu 0,106 dan $\mathrm{R}$ square atau koefisien determinasi 0,011 sehingga dapat ditafsirkan bahwa gaya belajar memiliki kontribusi pengaruh yang sangat kecil yaitu $1,1 \%$ saja.lainnya dipengaruhi oleh faktor2 lain

\begin{tabular}{|c|c|c|c|c|c|c|}
\hline \multicolumn{7}{|c|}{ Anovg ${ }^{b}$} \\
\hline Vodel & & 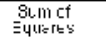 & af & 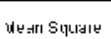 & $\mathrm{F}$ & Sig. \\
\hline 1 & Rutwressiur & 42,319 & 1 & 47,319 & $2 \cdot 3 E$ & $.1<3^{2}$ \\
\hline & Prي-i Ini & $3 \bar{T} \cdot ?$, fiR 1 & 197 & $16.9<0$ & & \\
\hline & Tillilal & 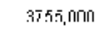 & 191 & & & \\
\hline
\end{tabular}

Hipotesis penelitian

Ho :Tidak terjadi hubungan linear antara gaya belajar terhadap hasil belajar

$\mathrm{H} 1$ : terjadi hubungan linear antara gaya belajar terhadap hasil belajar.

Ketentuan Jika sig $<0,05$ maka Ho ditolak Jika sig $>0,05$ maka Ho di terima

Diliat dari tabel anova didapat bahwa sig 0,143>0,05 maka Ho diterima berarti Tidak terjadi hubungan linear antara gaya belajar terhadap hasil belajar.

\begin{tabular}{|c|c|c|c|c|c|}
\hline \multirow[t]{2}{*}{ Inudtel } & Inolonca'di & cecticiert: & 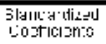 & \multirow[b]{2}{*}{1} & \multirow[b]{2}{*}{$8 g$} \\
\hline & R & Sitd Frnnr & Ripla & & \\
\hline (CLIIISterl) & 22952 & $6,<82$ & & 14333 &, $\mathrm{C05}$ \\
\hline gayo belalar & 22 & .11L & .106 & $4 / 2$ & .143 \\
\hline
\end{tabular}

Uji Koefisien

Hipotesis penelitian : Ho: Koefisien gaya belajar tidak signifikan

H1 : Koefisien gaya belajar signifikan Ketentuan Jika sig $<0,05$ maka Ho ditolak Jika sig $>0,05$ maka Ho di terima 
Dilihat dari signifikansi 0,143>0,05 maka Ho di terima berarti koefisien gaya belajar tidak signifikan

\section{Kesimpulan}

Tidak Terdapat pengaruh signifikan gaya belajar terhadap hasil belajar matematika SISWA kelas VIII SMPN 2 Banjarmasin tahun ajaran 2015/2016.

\section{Daftar Pustaka}

Abdussalam Al-khalili. 2005. Amal, Pengembangan kreatifitas anak, $(\mathrm{Hj}$ Umma Farida, terjemahan). Jakarta: Pustaka Al-Kautsar.

Arikunto, Suharsimi. 1999. Dasar-dasar Evaluasi Pendidikan. Jakarta: Bumi Aksara.

Arikunto, Suharsimi. 2000. Manajemen Penelitian. Jakarta: Rineka Cipta.

Arikunto, Suharsimi . 2006. Prosedur Penelitian Suatu Pendekatan Praktik. Jakarta : Rineka Cipta.

Chandra, Julius. 1994. Kreatifitas, Bagaimana menanam, Membangun dan Mengembangkannya Yogyakarta:Kanisius.

DePotter, Bobbi , Mike Hernacki. 1999. Quantum Learning. Bandung: Kaifa.

Hurlock, Elizabeth B. 2002. Perkembangan Anak Jilid 2 (Meitasari Tjandrasa. Terjemahan).Jakarta: Erlangga.

Nasution. 2008. Berbagai Pendekatan dalam Proses Belajar Mengajar. Cetakan ke-11 Jakarta: Bumi Aksara.
Purwanto M, Ngalim. 2003. Psikologi Pendidikan.Bandung: PT Remaja Rosdakarya.

Semiawan, Conny. 1997. Perspektif Pendidikan Anak Berbakat. Jakarta: PT Gramedia Widiasarana Indonesia.

Slameto. 2003. Belajar dan Faktor-faktor yang Mempengaruhinya.Jakarta: PT Rineka Cipta.

Sudjana, Nana. 2003. Metode Statistika. Bandung: Tarsito.

Sudjana, Nana. 1989. Penilaian Hasil Proses Belajar Mengajar.Bandung: Rosda Karya.

Sudjana, Nana. 2004. Penilaian Hasil Proses Belajar Mengajar. Bandung: Rosda Karya.

Sudijono, Anas .2008. Pengantar Statistik pendidikan. Jakarta: Raja Grafindo Persada.

Sugiyono. 2009. Metode Penelitian Pendidikan Pendekatan Kuantitatif. Bandung: CV Alfa Beta.

Tim Penulis Departemen Pendidikan Nasional. 2003. Standar Kompetensi Mata Pelajaran Matematika Sekolah Menengah Pertama dan Madrasah Tsanawiyah. Jakarta: Pusat Kurikulum Balitbang Depdiknas.

Usman, Husaini. 2009. Pengantar Statistika. Jakarta: Bumi Aksara.

Nasution. 1982. Didaktik Azas-Azas Mengajar. Jakarta: Grasindo. 